\title{
Pengaruh Antibakteri Ekstrak Kulit Batang Matoa (Pometia pinnata) terhadap Bakteri Staphylococcus aureus secara In vitro
}

\author{
Mercy Ngajowa*, Jemmy Abidjulua , Vanda S. Kamua \\ aJurusan Kimia, FMIPA, Unsrat, Manado
}

\begin{tabular}{l} 
K A T A K U N C I \\
\hline Antibakteri \\
Matoa (Pometia pinnata) \\
Staphylococcus aureus
\end{tabular}

KEYW O R D S

Antibacteria

Matoa (Pometia pinnata)

Staphylococcus aureus

\begin{abstract}
A B S T R A K
Telah dilakukan penelitian secara kualitatif terhadap pengaruh antibakteri dari ekstrak kulit batang matoa (Pometia pinnata. Spp.) terhadap bakteri Gram positif Staphylococcus aureus. Sebelum dilakukan uji antibakteri, sampel yang telah diekstrak secara maserasi diuji fitokimia terlebih dahulu untuk menentukan kandungan metabolit sekunder yang telah diketahui berperan sebagai agen antibakteri. Setelah dilakukan uji fitokimia, ekstrak diuji aktivitas antibakterinya terhadap bakteri Staphylococcus aureus dengan menggunakan teknik difusi agar dengan cara sumuran. Ekstrak dilarutkan pada aquades steril dengan perbandingan 2 g ekstrak pada $2 \mathrm{~mL}$ air. Untuk kontrol positif, digunakan ciprofloxacin dan aquades steril sebagai kontrol negatif. Hasil penelitian ini menunjukkan bahwa ekstrak kulit batang matoa memiliki aktivitas antibakteri setelah diinkubasi selama 24 jam pada $37{ }^{\circ} \mathrm{C}$. Dari 3 kali pengulangan dengan masing - masing 3 sumuran, didapat zona hambat masing - masing $16.84 \mathrm{~mm}, 12.5 \mathrm{~mm}$ dan $14.5 \mathrm{~mm}$ dengan kontrol positif $29.67 \mathrm{~mm}$ serta kontrol negatif $0 \mathrm{~mm}$. Hasil yang diperoleh didukung oleh keberadaan metabolit sekunder hasil uji fitokimia yaitu tanin, flavonoid, terpenoid dan saponin.

A B S T R A C T

A qualitative study has done of the antibacterial effect of matoa (Pometia pinnata) stem bark extract against Gram-positive bacteria Staphylococcus aureus. Before the antibacterial test, samples were extracted by maceration and then phytochemical tested to measuring the content of secondary metabolites that have been known to act as an antibacterial agent. After being tested of phytochemical, extracts were tested the antibacterial effect against Staphylococcus aureus using agar diffusion technique. Extract was dissolved in sterile distilled water with a ratio of $2 \mathrm{~g}$ of extract in $2 \mathrm{~mL}$ of water. For the positive control, use of ciprofloxacin and sterile distilled water as a negative control. Results of this study indicate that matoa bark extract has antibacterial effect after incubation for $24 \mathrm{~h}$ at $37^{\circ} \mathrm{C}$. Of 3 times with each repetition - each 3 wells, the inhibition zone obtained - each $16.84 \mathrm{~mm}, 12.5 \mathrm{~mm}$ and $14.5 \mathrm{~mm}$ with $29.67 \mathrm{~mm}$ of positive control and a negative control by $0 \mathrm{~mm}$. The results are supported by the presence of secondary metabolites by phytochemical test such as tannins, flavonoids, terpenoids and saponins.
\end{abstract}

AVAILABLE ONLINE

08 November 2013

*Corresponding author: Jurusan Kimia FMIPA UNSRAT, Jl. Kampus Unsrat, Manado, Indonesia 95115; Email address: mercyngajouw@gmail.com Published by FMIPA UNSRAT (2013) 


\section{Pendahuluan}

Negara Indonesia adalah negeri yang kaya akan keanekaragaman hayati yang dimiliki oleh hewan dan tumbuhannya. Khusus untuk tumbuhan, ada begitu banyak spesies yang beraneka-ragam di sekitar kita yang bisa kita manfaatkan untuk menunjang kehidupan kita, baik sebagai bahan makanan, maupun sebagai bahan untuk obat. Pemanfaatan tanaman sebagai obat akhir-akhir ini semakin populer di masyarakat. Semakin mahalnya harga obat-obatan membuat masyarakat mencari alternatif lain untuk pengobatan yakni dengan memanfaatkan tanaman yang berkhasiat obat.

Matoa adalah tanaman yang belum dimaksimalkan manfaatnya sebagai tanaman obat di wilayah Sulawesi Utara. Sejauh ini, yang terkenal dari tanaman ini adalah buahnya dengan rasa yang khas. Peneliti sebelum-sebelumnya hanya mengkaji tanaman ini sebagai tanaman yang berkhasiat obat dengan meneliti metabolit sekunder yang terkandung di dalamnya.

Di sisi lain, meningkatnya pola hidup masyarakat mengakibatkan munculnya bermacammacam penyakit yang biasanya diakibatkan oleh mikroorganisme, misalnya bakteri. Untuk solusi, biasanya digunakan suatu formula yang mengandung zat untuk menghambat pertumbuhan bakteri tersebut, atau bahkan membunuhnya. Zat ini umum dikenal sebagai antibakteri dan dalam dunia medis lebih dikenal dengan antibiotik (Fluit dan Schmitz, 2003).

Sementara itu, penggunaan formula yang disintesis umumnya menimbulkan efek samping bagi tubuh yang tak jarang merugikan penggunanya. Selain itu, resitensi bakteri terhadap antibiotik semakin mengkhawatirkan setelah munculnya strain bakteri yang kebal terhadap beberapa antibiotik yang umum digunakan (Cavalieri et al., 2005).

Berdasarkan latar belakang di atas, maka dilakukan penelitian tentang aktivitas antibakteri dengan kulit batang matoa sebagai objek untuk diambil ekstraknya dengan bioindikator bakteri Staphylococcus aureus.

Penelitian ini bertujuan untuk mengetahui pengaruh antibakteri ekstrak kulit batang matoa terhadap bakteri Staphylococcus aureus secara In vitro.

\section{Metode}

Penelitian ini dilaksanakan di Laboratorium Biokimia, Laboratorium Advans, dan Laboratorium Mikrobiologi FMIPA UNSRAT pada bulan AgustusSeptember 2013.

\subsection{Alat}

Peralatan yang digunakan dalam penelitian ini adalah oven, aluminium foil, timbangan analitik, blender, ayakan 65 mesh, bejana kaca, batang pengaduk, gelas ukur, kertas saring, gelas kimia, rotary evaporator, inkubator, kawat ose, api bunsen, jangka sorong, cawan petri, autoklaf, Erlenmeyer, gelas ukur, gelas kimia dan tabung reaksi.

\subsection{Bahan}

Bahan yang digunakan dalam penelitian ini adalah kulit batang matoa, aquades, etanol 95\%, amoniak, kloroform, asam asetat anhidrat, pereaksi Lieberman - Burnchard, asam klorida, Nutrient Agar (NA), asam sulfat, bubuk magnesium, pereaksi Dragendorff, $\mathrm{FeCl}_{3}$, larutan $\mathrm{BaCl}_{2} .2 \mathrm{H}_{2} \mathrm{O}$ 1,175\%, larutan $\mathrm{NaCl} 0,9 \%$, bakteri Staphylococcus aureus, aquades steril sebagai kontrol negatif, dan cyprofloxacin sebagai kontrol positif.

\subsection{Prosedur Penelitian}

\subsubsection{Preparasi Sampel}

Sampel utama dari penelitian ini adalah kulit batang Matoa yang diambil dari perkebunan warga Desa Kalipitu Kecamatan Tobelo Tengah Halmahera Utara. Dibersihkan dan dikeringanginkan selama 3 hari, kemudian digiling menjadi serbuk dan diayak dengan ukuran 65 mesh.

\subsubsection{Ekstraksi}

Kulit batang yang telah menjadi serbuk diambil 50 g kemudian dimaserasi 2 kali dengan $500 \mathrm{~mL}$ etanol 95\% selama $6 \times 24$ jam, kemudian disaring dengan kertas saring dan dievaporasi dengan rotary evaporator. Setelah itu, sample dimasukkan kedalam oven selama 1 × 24 jam pada $102^{\circ} \mathrm{C}$, kemudian disimpan dalam desikator. Setelah itu dihitung rendemen ekstrak dengan menggunakan rumus :

$$
\frac{\text { Berat Ekstrak }}{\text { Berat Sampel }} \times 100
$$

\subsubsection{Analisis Fitokimia (Harborne, 1987)}

\subsubsection{Analisis senyawa alkaloid}

Sebanyak 2 g sampel tumbuhan yang telah dihaluskan ditambahkan kloroform secukupnya lalu dihaluskan lagi. Kemudian ditambah $10 \mathrm{ml}$ amoniak dan $10 \mathrm{ml}$ kloroform. Larutan disaring ke dalam tabung reaksi, dan filtrat ditambahkan asam sulfat $2 \mathrm{~N}$ sebanyak 10 tetes. Filtrat dikocok dengan teratur kemudian dibiarkan beberapa lama sampai terbentuk dua lapisan. Lapisan atas dipindahkan ke dalam tiga tabung reaksi masing-masing $2,5 \mathrm{ml}$. Ketiga larutan ini dianalisis dengan pereaksi Dragendorff. Terbentuknya endapan jingga dengan pereaksi Dragendorff menunjukkanhasil positif.

\subsubsection{Analisis senyawa triterpenoid dan steroid}

Sebanyak 2 g sampel tumbuhan yang telah dihaluskan, ditempatkan pada plat tetes dan ditambahkan asam asetat anhidrat sampai sampel terendam semuanya, dibiarkan selama kira-kira 15 menit, enam tetes larutan dipindahkan ke dalam tabung reaksi dan ditambah 2-3 tetes asam sulfat pekat. Adanya triterpenoid ditunjukkan dengan terjadinya warna merah, jingga atau ungu, 
sedangkan adanya steroid ditunjukkan dengan adanya warna biru.

\subsubsection{Analisis senyawa flavanoid}

Sebanyak 2 g sampel tumbuhan yang telah diekstrak dengan $5 \mathrm{ml}$ etanol, dipanaskan selama lima menit di dalam tabung reaksi. Selanjutnya ditambah beberapa tetes $\mathrm{HCl}$ pekat. Kemudian ditambahkan 0,2 g bubuk Mg. Hasil positif ditunjukkan dengan timbulnya warna merah tua dalam waktu 3 menit.

\subsubsection{Analisis senyawa saponin}

Sebanyak 2 g sampel tumbuhan yang telah dihaluskan dimasukkan ke dalam tabung reaksi, ditambah air suling sehingga seluruh cuplikan terendam, dididihkan selama 2-3 menit, dan selanjutnya didinginkan, kemudian dikocok kuatkuat. Hasil positif ditunjukkan dengan terbentuknya buih yang stabil.

\subsubsection{Analisis senyawa tanin}

Sebanyak 2 g sampel tumbuhan yang telah dihaluskan, ditambah etanol sampai sampel terendam semuanya. Kemudian sebanyak $1 \mathrm{ml}$ larutan dipindahkan kedalam tabung reaksi dan ditambahkan 2-3 tetes larutan $\mathrm{FeCl}_{3}$ 1\%. Hasil positif ditunjukkan dengan terbentuknya warna hitam kebiruan atau hijau.

\subsubsection{Uji Aktivitas Antibakteri}

Untuk metode uji antibakteri diadaptasi dari metode Lay (1994) dengan menggunakan teknik Sumuran (Difusi Agar) yang telah dimodifikasi.

Pertama - tama, alat-alat non gelas disterilkan terlebih dahulu di dalam autoklaf pada suhu $121^{\circ} \mathrm{C}$ selama 15 menit dan alat-alat gelas disterilkan di oven suhu $160-170^{\circ} \mathrm{C}$ selama 2 jam. Jarum ose dibakar dengan api bunsen.

\subsubsection{Pembuatan Media}

\section{a. Media Agar Miring}

Diambil Nutrient Agar (NA) sebanyak 0,46 g dilarutkan dalam $20 \mathrm{~mL}$ aquades (23 g/1000 mL) menggunakan erlenmeyer. Selanjutnya dihomogenkan dengan stirrer di atas penangas air sampai mendidih. Sebanyak $5 \mathrm{~mL}$ dituangkan masing-masing pada 3 tabung reaksi steril dan ditutup dengan aluminium foil. Media disterilkan dalam autoklaf dengan suhu $121^{\circ} \mathrm{C}$ selama 15 menit, kemudian dibiarkan pada suhu ruangan selama \pm 30 menit sampai media memadat pada kemiringan $30^{\circ}$. Media agar miring digunakan untuk inokulum bakteri.

\section{b. Media Dasar dan Media Pertumbuhan}

Media dasar dibuat dengan cara ditimbang Nutrient Agar (NA) sebanyak 2,3 gram, lalu dilarutkan dalam $100 \mathrm{~mL}$ aquades (23 g/1000 mL) menggunakan Erlenmeyer. Sedangkan media pembenihan dibuat dengan cara ditimbang 4,6 g $\mathrm{NA}$, lalu dilarutkan dalam $100 \mathrm{~mL}$ aquades (46 $\mathrm{g} / 1000 \mathrm{~mL}$ ) menggunakan Erlenmeyer. Setelah itu, masing-masing media dihomogenkan dengan stirer diatas penangas air sampai mendidih. Media-media yang sudah homogen ini disterilkan dalam autoklaf pada suhu $121^{\circ} \mathrm{C}$ selama 15 menit, kemudian didinginkan sampai suhu $\pm 45-50{ }^{\circ} \mathrm{C}$. Media dasar dan media pembenihan digunakan dalam pembuatan media pengujian sebagai lapisan dasar dan lapisan kedua.

\subsubsection{Pembuatan Standar Kekeruhan Larutan (Larutan Mc. Farland)}

Larutan asam sulfat 0,36 $\mathrm{N}$ sebanyak 99,5 mL dicampurkan dengan larutan $\mathrm{BaCl} 2.2 \mathrm{H} 2 \mathrm{O}$ 1,175\% sebanyak 0,5 $\mathrm{mL}$ dalam Erlenmeyer kemudian dikocok sampai terbentuk larutan yang keruh. Kekeruhan ini dipakai sebagai standar kekeruhan suspensi bakteri uji.

\subsubsection{Pembuatan Suspensi Bakteri Uji}

Bakteri uji pada media agar miring diambil dengan kawat ose steril lalu disuspensikan ke dalam tabung yang berisi $2 \mathrm{~mL}$ larutan $\mathrm{NaCl} 0,9 \%$ hingga diperoleh kekeruhan yang sama dengan standar kekeruhan larutan Mc. Farland.

\subsubsection{Pembuatan Media Pengujian}

Lapisan dasar dibuat dengan menuangkan masing-masing $10 \mathrm{~mL}$ NA ke dalam 3 cawan petri, kemudian dibiarkan memadat. Setelah memadat, permukaan lapisan dasar ditanam 5 pencadang baja yang diatur jaraknya agar daerah pengamatan tidak bertumpu. Suspensi bakteri dicampurkan ke dalam media pembenihan NA. Selanjutnya dituangkan $25 \mathrm{~mL}$ NA pada tiap cawan petri yang diletakkan pencadang sebagai lapisan kedua.Setelah lapisan kedua memadat, pecadang diangkat menggunakan pinset dari masing-masing cawan petri, sehingga terbentuk sumur-sumur yang akan digunakan dalam uji bakteri.

\subsubsection{Penentuan Aktivitas Antibakteri}

Kegiatan ini dibuat untuk mengetahui aktivitas antibakteri ekstrak etanol kulit batang matoa yang dilakukan dengan metode difusi agar, dengan cara mengukur diameter hambatan pertumbuhan bakteri terhadap bakteri Staphylococcus aureus. Cara penentuannya adalah sebagai berikut : sumuran yang sudah dibuat pada media pengujian diteteskan larutan uji yaitu ekstrak yang dilarutkan dalam aquades steril sebanyak 2 gr dalam $2 \mathrm{~mL}$ aquades sebanyak $50 \mu \mathrm{l}$ menggunakan mikropipet, kemudian diinkubasi dalam inkubator pada suhu $37^{\circ} \mathrm{C}$ selama 24 jam, setelah itu dilihat ada tidaknya zona hambat yang terbentuk. Jika ada, diukur diameter daerah hambatan di sekitar pencadang menggunakan jangka sorong dengan cara mengukur secara horizontal dan vertikal kemudian hasil yang didapat dikurangi diameter sumuran 7 $\mathrm{mm}$.

\section{Hasil dan Pembahasan \\ 3.1. Ekstraksi Kulit Batang Matoa}

Setelah dimaserasi, rendemen diperoleh sebanyak 27.2\% atau sama dengan 13.6 g ekstrak yang berwarna merah - kecokelatan. Selanjutnya 
ekstrak dianalisis fitokimia terlebih dahulu lalu diuji aktivitas antibakteri.

\subsection{Analisis Fitokimia}

Dari hasil analisis fitokimia secara kualitatif ditemukan terdapat kandungan metabolit sekunder pada ekstrak etanol kulit batang matoa. Hasil analisis fitokimia menunjukan bahwa ekstrak etanol kulit batang matoa mengandung senyawa flavonoid, tanin, terpenoid dan saponin yang disajikan dalam Tabel 1.

Tabel 1. Hasil analisis fitokimia ekstrak kulit batang matoa

\begin{tabular}{ll}
\hline Analisis & Hasil Tes \\
\hline Alkaloid & - \\
Steroid & -
\end{tabular}

\begin{tabular}{lc} 
Saponin & + \\
Triterpenoid & + \\
Tanin & + \\
Flavonoid & + \\
\hline Keterangan : & $(-) \quad:$ tidak terdeteksi \\
& $(+)$ : terdeteksi
\end{tabular}

Uji fitokimia dilakukan untuk melihat kandungan metabolit sekunder dalam sampel uji sehingga memperkuat gagasan penulis bahwa kulit batang matoa memiliki potensi sebagai bakteri karena menurut Cowan (1999), senyawa golongan fenolik memiliki efektifitas yang tinggi sebagai agen antibakteri.

\subsection{Uji Aktivitas Antibakteri}

Dengan metode difusi agar (sumuran) dilakukan uji antibakteri ekstrak terhadap bakteri Stphylococcus aureus. Hasil positif jika terbentuk zona hambat di sekitar sumuran. Setelah diinkubasi selama 24 jam pada suhu $37^{\circ} \mathrm{C}$, hasilnya dilihat dengan membandingkan ekstrak dengan kontrol positif dan kontrol negatif.

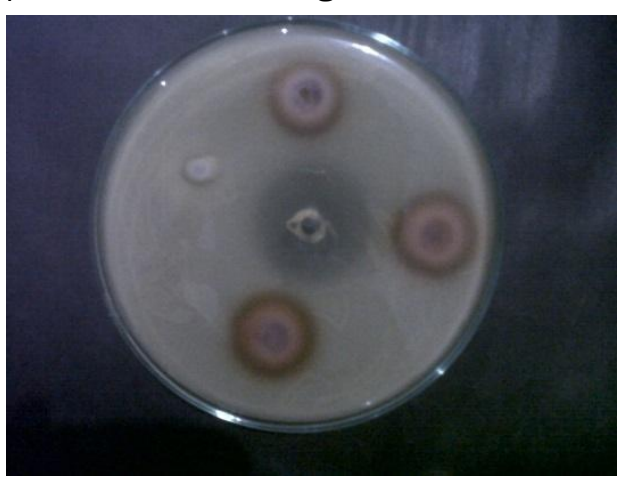

Gambar 1. Hasil Uji Anti Bakteri Ekstrak Etanol Kulit Batang Matoa terhadap Bakteri Staphylococcus aureus.

Dari hasil pengamatan terhadap sumuran yang berisi ekstrak kulit batang matoa menunjukkan hasil positif dengan terbentuknya zona hambat di sekitar sumuran. Hal ini disebabkan oleh keberadaan metabolit sekunder sehingga memberikan pengaruh terhadap pertumbuhan bakteri uji.

Setelah dilihat pengujian menunjukkan hasil positif, selanjutnya dilakukan pengukuran untuk mengetahui diameter zona hambat dari masingmasing sampel ekstrak dan larutan kontrol

Dari 3 kali pengulangan dengan masing - masing 3 sumuran, didapat hasil yang bisa dilihat pada Tabel 2.

Tabel 2. Hasil Pengukuran Diameter Zona Hambatan

\begin{tabular}{ll}
\hline & Rata - rata Diameter $(\mathrm{mm})$ \\
\hline Ulangan 1 & 16.84 \\
Ulangan 2 & 12.5 \\
Ulangan 3 & 14.5 \\
Kontrol Positif & 29.67 \\
Kontrol Negatif & 0 \\
\hline
\end{tabular}

Keberadaan metabolit sekunder menjadi faktor penting melalui mekanismenya terhadap bakteri. Mekanisme kerja tanin sebagai antibakteri adalah menghambat enzim reverse transkriptase dan DNA topoisomerase sehingga sel bakteri tidak dapat terbentuk (Nuria et al., 2009). Tannin memiliki aktifitas antibakteri yang berhubungan dengan kemampuannya untuk menginaktifkan adhesin sel mikroba juga menginaktifkan enzim, dan menggangu transport protein pada pada lapisan dalam sel (Cowan, 1994). Menurut Sari dan Sari (2011), tanin juga mempunyai target pada polipeptida dinding sel sehingga pembentukan dinding sel menjadi kurang sempurna. Hal ini menyebabkan sel bakteri menjadi lisis karena tekanan osmotik maupun fisik sehingga sel bakteri akan mati. Selain itu, menurut Akiyama et al. 2001, kompleksasi dari ion besi dengan tanin dapat menjelaskan toksisitas tanin. Mikroorganisme yang tumbuh di bawah kondisi aerobik membutuhkan zat besi untuk berbagai fungsi, termasuk reduksi dari prekursor ribonukleotida DNA. Hal ini disebabkan oleh kapasitas pengikat besi yang kuat oleh tanin.

Mekanisme kerja flavonoid sebagai antibakteri adalah membentuk senyawa kompleks dengan protein ekstraseluler dan terlarut sehingga dapat merusak membrane sel bakteri dan diikuti dengan keluarnya senyawa intraseluler (Cowan, 1999 ; Nuria et al., 2009 ; Bobbarala, 2012). Menurut Cushnie dan Lamb (2005), selain berperan dalam inhibisi pada sintesis DNA - RNA dengan interkalasi atau ikatan hidrogen dengan penumpukan basa asam nukleat, flavonoid juga berperan dalam menghambat metabolisme energi. Senyawa ini akan mengganggu metabolisme energi dengan cara yang mirip dengan menghambat sistem respirasi, karena dibutuhkan energi yang cukup untuk penyerapan aktif berbagai metabolit dan untuk biosintesis makromolekul. 
Senyawa terpenoid juga diketahui aktif melawan bakteri, tetapi mekanisme antibakterial triterpenoid masih belum benar-benar diketahui. Aktifitas antibakteri terpenoid diduga melibatkan pemecahan membran oleh komponen-komponen lipofilik (Cowan, 1999 ; Bobbarala, 2012). Selain itu, menurut Leon et al. (2010), senyawa fenolik dan terpenoid memiliki target utama yaitu membran sitoplasma yang mengacu pada sifat alamnya yang hidrofobik.

Mekanisme kerja saponin sebagai antibakteri adalah menurunkan tegangan permukaan sehingga mengakibatkan naiknya permeabilitas atau kebocoran sel dan mengakibatkan senyawa intraseluler akan keluar (Nuria et al. 2009). Menurut Cavalieri et al. (2005), senyawa ini berdifusi melalui membran luar dan dinding sel yang rentan, lalu mengikat membran sitoplasma dan mengganggu dan mengurangi kestabilan itu. Hal ini menyebabkan sitoplasma bocor keluar dari sel yang mengakibatkan kematian sel. Agen antimikroba yang mengganggu membran sitoplasma bersifat bakterisida.

Menurut Davis dan Stout (1971), ketentuan antibakteri adalah sebagai berikut ; daerah hambatan $20 \mathrm{~mm}$ atau lebih berarti sangat kuat, daerah hambatan $10-20 \mathrm{~mm}$ berarti kuat, 5 - 10 $\mathrm{mm}$ berarti sedang, dan daerah hambatan $5 \mathrm{~mm}$ atau kurang bararti lemah.

Dengan hasil yang di dapat di atas, bisa disimpulkan bahwa kulit batang matoa memiliki pengaruh antibakteri yang kuat terhadap bakteri Staphylococcus aureus, karena rata - rata diameter berada di kisaran 10 - $20 \mathrm{~mm}$. Hal ini didukung oleh hasil positif terhadap uji fitokimia.

\section{Kesimpulan}

Berdasarkan hasil penelitian dari ekstrak etanol kulit batang matoa terhadap bakteri Staphylococcus aureus, dapat disimpulkan bahwa kulit batang matoa memiliki pengaruh yang kuat sebagai antibakteri terhadap bakteri uji.. Hal ini karena kulit batang matoa mengandung tannin, flavonoid, triterpenoid dan saponin yang efektif sebagai agen antibakteri.

\section{Daftar Pustaka}

Akiyama, H., K. Fujii., O. Yamasaki., T. Oono., dan K. Iwatsuki. 2001. Antibacterial Action of Several
Tannin against Staphylococcus aureus. Journal of Antimicrobial Chemotherapy. 48: 487 - 491.

Bobbarala, V. 2012. Antimicrobial Agents. Intech, Croatia.

Cavalieri, S.J., I.D. Rankin., R.J. Harbeck., R.S. Sautter., Y.S. McCarter., S.E. Sharp., J.H. Ortez., dan C.A. Spiegel. 2005. Manual of Antimicrobial Susceptibility Testing. American Society for Microbiology, USA.

Cowan, M.M. 1999. Plant Products as Antimicrobial Agents. Clinical Microbiology Reviews. 12: 564 582.

Cushnie, T.P.T., dan A.J. Lamb. 2005. Antimicrobial Activity of Flavonoids. International Journal of Antimicrobial Agents. 26: 343 - 356.

Davis, W.W., dan T. R. Stout. 1971. Disc Plate Method of Microbiological Antibiotic Assay. Applied Microbiology. 22: 659 - 665.

Fluit, A.C., dan F.J. Schmitz. 2003. MRSA Current Perspectives. Caster Academic Press, England.

Harborne, J. B. 1987. Metode Fitokimia: Penuntun Cara Modern Menganalisis Tumbuhan. Terjemahan Padmawinata dan I Sudiro; InstitutTeknologi Bandung, Bandung.

Lay, B.W. 1994. Analisa Mikroba di Laboratorium. Raja Grafindo Persada, Jakarta.

Leon, L.D., M.R. Lopez., dan L. Moujir. 2010. Antibacterial Properties of Zeylasterone a Triterpenoid Isolated from Maytenus blepharacles against Staphylococcus aureus. Microbiological Research. 12: 2 - 10.

Nuria, M.C., A. Faizatun., dan Sumantri. 2009. Uji Antibakteri Ekstrak Etanol Daun Jarak Pagar ( Jatropha cuircas L) terhadap Bakteri Staphylococcus aureus ATCC 25923, Escherichia coli ATCC 25922, dan Salmonella typhi ATCC 1408. Jurnal IImu - ilmu Pertanian. 5: 26 - 37.

Sari, F.P., dan S. M. Sari. 2011. Ekstraksi Zat Aktif Antimikroba dari Tanaman Yodium (Jatropha multifida Linn) sebgai Bahan Baku Alternatif Antibiotik Alami. Fakultas Teknik Universitas Diponegoro, Semarang.

Tadesse, A., dan M. Alam. 2006. Medical Bacteriology. University of Gondar, Ethiopia.

Tenover, F.C. 2006. Mechanisms of Antimicrobial Resistance in Bacteria. The American Journal of Medicine. 119: 3 - 10. 